\title{
Wyrok Sądu Metropolitalnego w Katowicach (c. Sobański) z 28.11.2002 r. $z$ tytułu niezdolności do podjęcia istotnych obowiązków małżeńskich
}

Ius Matrimoniale 8 (14), 221-230

2003

Artykuł został zdigitalizowany i opracowany do udostępnienia w internecie przez Muzeum Historii Polski w ramach prac podejmowanych na rzecz zapewnienia otwartego, powszechnego i trwałego dostępu do polskiego dorobku naukowego i kulturalnego. Artykuł jest umieszczony w kolekcji cyfrowej bazhum.muzhp.pl, gromadzącej zawartość polskich czasopism humanistycznych i społecznych.

Tekst jest udostępniony do wykorzystania w ramach dozwolonego użytku. 


\section{$\begin{array}{llllllllllllllllll}\text { O } & R & Z & \text { E } & \text { C } & \text { Z } & \text { N } & \text { I } & \text { C } & \text { T } & \text { W } & \text { O } & \text { S } & \text { A } & \text { D } & \text { O } & \text { W } & \text { E }\end{array}$ \\ Ius Matrimoniale \\ 8 (14) 2003}

\section{Wyrok Sądu Metropolitalnego w Katowicach (c. Sobański) z 28.11.2002 r. $\mathrm{z}$ tytułu niezdolności do podjęcia istotnych obowiązków małżeńskich.}

\section{Przebieg sprawy:}

A. M. oraz J. D., zawarli małżństwo 7.9 .1996 w kościele parafialnym w Katowicach. Ważność tego małżeństwa zaskarżyła J. D. 6.11.2000 r. w Sądzie Metropolitalnym w Katowicach. Sprawę przyjęto do procesu 13.12.2000. Jego przedmiot ustalono 29.12.2000 w formie pytania, czy zachodzi nieważność małżeństwa z tytułu niezdolności do podjęcia istotnych obowiązków małżeńskich po jednej i drugiej stronie. Sprawę trzeba było prowadzić bez udziału pozwanego, gdyż ten nie zjawił się do złożenia zeznań.

\section{Motywy prawne:}

Każdy człowiek ma niezbywalne prawo do zawarcia malżeństwa, chyba że prawo pozytywne dla określonych przyczyn wprowadza pewne ograniczenia. Prawo to czlowiek realizuje - czyli zawiera małżenstwo - przez akt woli zwany zgodą małżeńską. Ten akt woli powoduje zaistnienie malżeństwa, jeśli jest aktem wolnym, świadomym, zgodnym $\mathrm{z}$ wewnętrznymi zamiarami nupturienta $\mathrm{i}$ wyrażonym zgodnie z prawem. Dlatego prawo kościelne określa braki zgody małżeńskiej, które mogą wynikać z niewystarczającego rozeznania, ograniczenia wolności, niezdolności fizycznej lub psychicznej do małżeństwa, niezgodnych $\mathrm{z}$ istotą małżeństwa zamierzeń.

Konsekwencją powyższych założeń jest k. 1095, którzy brzmi: „Niezdolni do zawarcia małżeństwa są ci, którzy: (1) są pozbawieni wystarczającego używania rozumu; (2) mają poważny brak rozeznania oceniającego co do istotnych praw i obowiązków małżeńskich wzajemnie przekazywanych i przyjmowanych; (3) z przyczyn natury psychicznej nie są zdolni podjąć istotnych obowiązków małżeńskich". 
Wspólne wszystkim trzem dyspozycjom k. 1095 jest to, że określone w nich podstawy nieważności wywodzą się z przyczyn natury psychicznej, zaś ci, u których takie przyczyny zachodzą, są uznani za niezdolnych do zawarcia małżeństwa.

W dwóch pierwszych chodzi o psychiczne elementy samego konsensu małżeńskiego, w trzecim zaś o przedmiot tego konsensu. Czyli: w dwóch pierwszych chodzi o samą psychiczną zdolność do świadomego wyrażenia konsensu, w trzecim o zdolność do przekazania i przyjęcia tego wszystkiego, co w sposób istotny składa się na małżeństwo. W tym ostatnim przypadku rozeznanie i możność kierowania swym postępowaniem mogą nie podlegać brakom czy ograniczeniom, natomiast przejmowane i przekazywane prawa pozostają czcze, osoba jest do nich - tzn. do ich przyjęcia i wypełnienia - niezdolna z racji psychicznych. Uznając i doceniając odrębność tytułów nieważności małżeństwa z k. 1095 trzeba jednak stwierdzić, że w praktyce granica między nimi nie zawsze rysuje się dość wyraziście. Człowiek bowiem to pewna jedność i całość psychiczna, stąd mogą zachodzić takie przyczyny natury psychicznej, które pozbawiają go zarówno wystarczającego rozeznania, jak i zdolności do podjęcia i wypełnienia istotnych obowiązków malżeńskich.

„Zestawiając ze sobą nn. 1-2 oraz n. 3 kanonu należy powiedzieć, że także w obrębie nn. 1-2 kanonu podmiot jest niezdolny do podjęcia, a tym samym do wypełnienia istotnych obowiązków małżeńskich. Przy czym źródłem tej niezdolności pozostaje tutaj brak rozeznania oceniającego, występujący w sytuacjach objętych zarówno n. 1 jak i n. 2 kanonu" (W. Góralski - Prawo Kan. 39, 1996, 38). Stąd też w orzecznictwie kościelnym dość często przechodzi się z p. 2 do 3 kan. 1095, a w odniesieniu do orzecznictwa rotalnego wspomniano nawet o osmozie wskazanych w nich norm (sent. c. López-Illana z 19.2.1997 - RRT Decisiones, 89, 2002, $138 \mathrm{~ns}$.)

Zdolność do podjęcia i wypełnienia istotnych obowiązków małżeńskich zakłada ich poznanie, rozeznanie i krytyczną ocenę (stąd miejsce dyspozycji k. 1095 n. 3 po dyspozycjach dotyczących rozeznania krytycznego). To z kolei wymaga pewnej dojrzałości psychicznej, odpowiedniego rozwoju intelektualnego uzdalniającego do oceny praw i obowiązków małżeńskich, uczynienia ich przedmiotem własnej decyzji i konkretyzowania w życiu codziennym.

Funkcjonowanie wladz psychicznych - rozumu i woli - winno być wolne od zaburzeń, zwłaszcza w okresie formowania decyzji zawarcia 
małżeństwa (sent. c. Civili z 5.3.1997 - RRT Decisiones 89, 2002, 177). Zaburzenia te mogą być też powodowane przejściowymi okolicznościami towarzyszącymi znajomości przedślubnej - wtedy, gdy okoliczności te oddziaływają na umysł uniemożliwiając ocenę sytuacji i rozważenie motywów zawarcia małżeństwa, gdy powodują napięcie emocjonalne osłabiające zdolność krytycznego myślenia, czy też gdy psychikę zakłócają idee natrętne, obsesje, bezzasadne wyrzuty sumienia.

W ocenie, czy dojrzałość i rozwój psychiczny pozostaje odpowiedni i wystarczający do zawarcia małżeństwa, trzeba wziąć pod uwagę z jednej strony - prawo każdej osoby ludzkiej do zawarcia małżeństwa oraz - z drugiej strony - istotę małżeństwa oraz składających się na nie praw i obowiązków. Znaczy to - z jednej strony - iż wymogów do zawarcia małżeństwa nie wolno posuwać zbyt wysoko, by nie zamknąć drogi do małżeństwa osobom o ograniczonym rozeznaniu czy utrudnionej zdolności wykonywania obowiązków małżeńskich, ale - z drugiej strony - nie wolno zejść poniżej granicy, poza którą nie jest już do spełnienia to, co składa się na elementy, prawa oraz obowiązki małżeńskie i czego zawierający małżeństwo mają prawo oczekiwać od drugiej strony. Wypośrodkowanie między prawem do malżeństwa i zdolnością do malżeństwa to węzłowy problem ustawodawstwa i orzecznictwa kościelnego.

W sprawach prowadzonych na podstawie k. 1095 prawo nakazuje Sądowi zasięgnąć opinii jednego lub kilku biegłych, „chyba że z okoliczności wynika, że jest bezużyteczne" (k. 1680). Opinie te stanowią ważki, ale nie jedyny środek dowodowy. Podlegają przeto - jak wszystkie dowody - ocenie i rozwadze sądu, który swą decyzję winien uzasadnić, zwłaszcza gdy odrzuca wnioski biegłych (k. 1579).

\section{Stan faktyczny:}

1. Powódka zeznaje: „Nasz zwiazek rozpadl się, ponieważ psychicznie nie bylam zdolna mieszkać z pozwanym, budować z nim rodzinę. Pozwany tak bardzo mnie zdominowat, tak bardzo chciat, żeby wszystko odbywato się wedlug tego, co on chciat, usitowat podporzadkować nasze życie sobie samemu. Nasze matżeństwo byto dla pozwanego jednym $z$ punktów osiagnięcia swoich celów, zrobienia kariery. Cechowata go chorobliwa ambicja, pozwany dla swojej kariery potrzebowat dobrej pra- 
cy, mieszkania, żony, która dobrze zarabia, czegoś czym można się pochwalić. (...) Mimo, że mieliśmy wszystko, pozwany chciat jeszcze odciagnać mnie od moich przyjaciót, nie akceptowat nikogo z mojej pracy, chcial, żeby nikt nie miat na mnie wplywu. Ten wplyw chcial mieć tylko on. Ja nie jestem osobq silnq psychicznie $i$ na wiele rzeczy się godzitam, wychodzac z zatożenia, że tak musi być. Doszto do tego, że moja najlepsza przyjaciótka nie miała wstępu do naszego domu. Pozwany bat się, że ktoś mi powie, że tak nie może być. Wiele osób mówito mi wcześniej, że nie powinnam wychodzic za pozwanego. Nie mylili się. Pozwany nie odzywat sie przez tydzien, bo coś mu się nie podobato. Kontrolowat moje pieniadze. Byt upoważniony na wszystkie konta. Żylismy z moich pieniedzy. On nie upoważnit mnie na swoje konta. Swoje pieniadze odktadat na bliżej nieokreślona przysztość. Ja zarabiałam bardzo dużo, nasze pensje byly porównywalne i to byt dla pozwanego problem. On nie znosit tego, że ja moglam zarabiać tyle, co on. To on musial zdobyć lepsza prace, awans. On wiedziat, że kiedy mam pieniadze, moge być niezależna, ale tak sie stato, ze pozwany doprowadzit do tego, że ja nie miatam pienie$d z y$, tak $\dot{z} e$ pierwszy raz w życiu musiatam pożyczać. Pozwany wiedziat, $\dot{z}$ jeżeli nie będe miata pieniędzy, nie będe też miata możliwości podejmowania samodzielnych decyzji. Pozwany dopiat swego. Bytam catkowicie zależna od pozwanego. Ja jestem osobq bardzo zgodnq. Wiele rzeczy akceptowatam dla dobra zwiazku. (...) To co byto najbardziej bolesne: brak rozmowy. Pozwany nie chciat ze mnq rozmawiać, bo np. przyszłam 15 min. później z pracy niż on. Wysytat mnie do psychiatry, mówiac, że jestem nienormalna. $W$ zdenerwowaniu rzucat kubkami $w$ ściane lub rozbijal piecyk. Wiedziat, w jaki sposób sprawić mi ból. Ja źle reaguje na krzyk, a on sie po prostu dart na mnie. Byt arogancki, a potem stal sie jeszcze agresywny. Krzyki byly takie, że moi sasiedzi dziwnie na mnie patrzyli i pytali, czy moga mi jakoś pomóc (ludzie zupetnie obcy). Ja nie krzycze, nie trzaskam drzwiami, nie wychodze z domu, raczej przyjmuje wszystko. Nie miałam nawet możliwości mówienia o mojej sytuacji, bo miatam bardzo ograniczone kontakty przez mojego męża. Rozmawiatam tylko $z$ osobami, z którymi bezpośrednio pracowatam. Nie wiedziatam, co robić, nie mogtam już wytrzymać. Ptakatam, nie spatam, nie chciatam wracać do domu. To wszystko zaczęto się po kilku miesiqcach matżenstwa, kiedy pozwany zauważyt, że nie wchodze w jakies ramki, nie pasuje do schematu swojego życia, który miat. Kiedy to sie zaczęto, moi rodzice zwrócili mi uwage na sprawe pieniędzy, do której ja nie przywiazywatam uwagi. Pozwany pochodzil z rodziny, która nie miala pieniędzy. 
Byt nastawiony przez rodziców na sukces, na dojście do niego. Na studiach pozwanemu ten brak pieniędzy przeszkadzat. On ich nie miat. Studiowat handel zagraniczny, gdzie normalnie studiuja ludzie bogatych rodziców. Kiedy skonczyt studia, poszedt do firmy konsultingowej domagając się awansów $i$ dużych pieniędzy. Byt zawzięty, chorobliwie pracowity, za wszelka cene dazyl do wybicia się. Jest racjonalny, bardzo dobrze kalkuluje swoje kroki, wiele $z$ decyzji podejmuje $z$ wyrachowania. Obecnie chyba doszedt do dobrego stanowiska, sadzac po ilości sekretarek, które mnie odsytaja, mówiac, że pozwany jest zajęty. Na rozprawie w sadzie cywilnym pozwany byl tak agresywny $i$ arogancki, że sędzia chcial go wyrzucić $z$ sali. Zreszta dostat za to kare pieniężna. Nasz zwiazek trwat ok. 1,5 roku, ale mieszkalismy tylko rok".

Przed ślubem powódka rozstawała się z pozwanym kilkakrotnie, ale pozwany reagowal zarzutami, że ona zmarnowała mu życie. Zeznaje: „Pytat jak ja sobie to wyobrażam, że skoro to już tak daleko zaszto, a ja chcę to przekreślic. Pozwany plakat, mówit, że chce mieć dom, rodzine, a ja mu odbieram te szanse. Takie zachowania pozwanego poglębialo moje wyrzuty sumienia. W końcu zgodzitam sie na zawarcie zwiazku z pozwanym. Bylo to duzym zaskoczeniem dla znajomych, bo nie byliśmy szczęśliwa parq chodzacq za raczke przez dlugi czas. Moi rodzice, których je nie chcialam słuchać, odradzali mi matżeństwo, szczególnie moja mama. Ona nie wtracata się w nasz zwiazek, ale dawała do zrozumienia, że pozwany patrzyl sie przede wszystkim na pieniaddze, że jest zupetnie inaczej wychowany: inny dom, inne wartości. Moje koleżanki w ogóle pytaty mnie, „kto to jest?”. W pracy też byto to zaskoczeniem. Nigdy nie mówitam, że jestem z kimś zwiazana. Nie bywaliśmy między ludźmi razem. To byt też mój wstyd, bo widziatam, że pozwany potrafit zrazić do siebie wszystkich. Trudno mi byto zabrać pozwanego na jakas impreze z pracy, skoro on wszystkich uważat za glabów $i$ jetopów. $W$ decyzji o malzeństwie bylo przede wszystkim poczucie obowiazku, nie byto milości, namiętności". Powódka radziła się psychiatry, brała środki uspakajające. Dziś uważa za sukces, że po dwu latach potrafi w ogóle mówić o przejściach związanych $\mathrm{z}$ małżeństwem i $z$ rozwodem.

2. Pozwany - jak już wspomniano - nie zjawil się w Sądzie. W odpowiedzi na przesłaną mu skargę oświadczył, iż nie zamierza ustosunkowywać się do postawionych zarzutów, zagroził, że „w przypadku dalszego dezawuowania” jego osoby wystąpi do sądu powszechnego „o ochronę dóbr osobistych"! 
3. Przesłuchano troje świadków.

Kiedy powódka swemu ojcu przedstawiła narzeczonego, ten wywarł dobre na nim wrażenie. Do tej znajomości podchodzila - zeznaje jej ojciec- ${ }_{2 z}$ bez emocji, euforii”. Po ślubie ojciec powódki odniósł wrażenie, że "pozwany zbyt dużą wagę przywiązywał do spraw materialnych $^{23}$. Powódka chodzila smutna, ale nie zwierzała się, odpowiedzą na pytania było milczenie i łzy. Gdy powódka telefonicznie poinformowala rodziców, że ,jest bardzo źle i nie będzie z pozwanym", żona świadka spotkała się z pozwanym, który „powiedział tylko, że on nie wie, o co córce chodzi, byl zdziwiony, co się stalo, że córka nie chce $z$ nim zyćc $\hat{c}^{2 z}$. Powódka stwierdzila, że nerwowo nie wytrzymuje takiego życia i z powodu pozwanego dostaje rozstroju nerwowego. Z opowiadań powódki świadek wie, że pozwany zachowywał się fatalnie, ,zacząl ją tarmosić, szarpać, strasznie krzyczeć, przeszukiwał szafy...". Świadek powiada: „2Pozwany chciał sprowadzić córkę do roli kobiety podporządkowanej jego woli, siedzącej przy garnkach, czekającej z obiadem, a to nie leżało w charakterze córki. (...) Ona znała świat i tu nagle ktoś chcial zamknąć ją w domu".

Koleżance powódki, M. B., pozwany zakazał wstępu do ich domu, bo bal się, iż wywiera ona zbyt duży wplyw na powódkę. Świadek podaje, że obydwu stronom zależało na tej znajomości, ale każda $z$ nich obiecywała sobie co innego. Stroną podtrzymującą tę znajomość był pozwany: „Pozwany wywierat na powódkę bardzo duża presję. Np. pozwany wiedzial, że jeżeli ma wymóc decyzje na powódce, to krzyczat na niq $i$ szantażowat jq emocjonalnie. Gdy pozwany dowiedziat się, że powódka nie chce wyjść za niego za mąz, wpadt w histerię. Tak, to prawda, że powódka przed ślubem brata środki uspakajajace. Powódka chciata mieć dom i rodzinę, ale obawiata się niezrównoważonego zachowania pozwanego, gdyż byt on agresywny i histeryczny. Rodziny stron sq bardzo tradycyjne. To także moglo wywierać presję na powódkę. Decyzja o ślubie stron byta dla mnie zaskoczeniem, ponieważ wiedzialam, w jakim stanie emocjonalnym jest powódka $i$ widziatam, że malżenstwo $z$ pozwanym będzie dla powódki czymś trudnym. Rodzice powódki chcieli, żeby powódka zalożyla rodzinę, rodzie powódki polubili pozwanego. Powódka byla zdolna do podjęcia obowiazków matżeńskich". Świadek wie od powódki, ze „po roku małżeństwa pozwany zaczął reagować

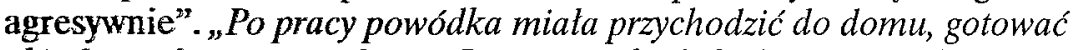
obiad $i$ spedzać czas w domu. Strony nie chodzity do znajomych $i$ wizyty u nich w domu tez byly czymśs sporadycznym. Pozwany byt osoba zabor- 
czq, bojqcq się zmiany sytuacji domowej. Pozwany byla arogancki i agresywny wobec powódki, jeśli coś nie bylo po jego myśli. Dla pozwanego byto najważniejsze to, jak postrzegaja go inni. Kiedy strony zaczęly się rozstawać $i$ wyprowadzit się z domu, pozwany śledzit powódkę, często $w$ nocy dobijat sie do domu. Pozwany nie chciat sie wyprowadzić $i$ zrobit to po dwóch miesiqcach od momentu, kiedy powódka powiedziata mu, ze chce się rozwiesć".

Również J. M., kolega powódki, przyjął wiadomość o ślubie stron $z$ dużym zaskoczeniem. Już w tydzień po ślubie „było coś nie tak między stronami". Pozwany ograniczał powódkę przy podejmowaniu decyzji, zabraniał jej kontaktów ze znajomymi, pozbawił ją pieniędzy $\mathrm{z}$ konta, a „w przyplywie agresji potrafil poniszczyć przedmioty w kuchni”. „U pozwanego było ogromny pęd na pozycję i karierę i na finanse $z$ tym związane" - powiada świadek.

3. W aktach sprawy znajduje się zaświadczenie wystawione 25.10.2000 przez dra M. S., specjalistę psychiatrę, wedle którego powódka „od maja 1996 do końca roku pozostawała pod stałą opieką psychiatryczną i stale przyjmowała leki psychotropowe".

4. Biegła proszona o opinię zwraca uwagę na szczupłość materiału dowodowego. Biegła pisze: „Przedstawiony materiat dowodowy nie jest wystarczajacy, aby wypowiadać sie jednoznacznie na temat wystepowania trwatych i powaznych zaburzeń osobowości u pozwanego. Nie można określić, czy prezentowane przez niego zachowania byly przejawem zaburzeń czy też prezentowat zachowania nieakceptowane przez powódkę. $\mathrm{Na}$ podstawie jej zeznań, można przypuszczać, że generalnie nie akceptowata pozwanego, nie podobaty jej sie jego zachowania, co nawet spowodowato, że chciata zerwać znajomość. Powódka podaje również, że kilkakrotnie korzystala z porad psychiatry, nawet przed zawarciem zwiazku matżeńskiego. $W$ zaświadczeniu lekarskim brakuje jednak rozpoznania oraz informacji na temat przyczyn ew. zaburzeń wystepujacych u powódki. Wiadomo natomiast, że matżonków dzielily różnice kulturowe, pochodzenie oraz status spoteczny. $Z$ tego powodu powódka nie byta akceptowana przez rodzinę pozwanego, co również moglo wplywać na wzajemne relacje matżonków. Można przypuszczać, że w miejscu pracy pozwany funkcjonowat prawidtowo, byt akceptowany przez pracodawców, często awansowat. Nie można powiedziec, aby pozwany byt osobq nieodpowiedzialnq, beztroskq, nie potrafiqcq nawiqzać gtębokiej więzi emocjonalnej. To on mówit o mitości do powódki, dqżyt do matzeństwa. Powódka jak twierdzi, wychodzita za mazż zobowiqzku, nie byto z jej strony mitości. Po- 
wyższe watpliwości nie pozwalaja $w$ chwili obecnej na wydanie opinii na temat braku zdolności ze strony pozwanego do podjecia $i$ wypetniania istotnych obowiazków matzeńskich. Powódka jawi sie jako osobo dojrzata, w pelni odpowiedzialna za swoje decyzje. Przedstawieni przez niq świadkowie nie wskazuja na wystepowanie u niej jakichkolwiek nieprawidtowości. Brak natomiast informacji na temat jej funkcjonowania w zwiazku matzeńskim i postrzegania jej osoby przez pozwanego". Konkluzja biegłej brzmi: „Na podstawie przedstawionego materiatu dowodowego nie jestem $w$ stanie wydać jednoznacznej opinii na temat braku zdolnosici natury psychicznej do podjecia $i$ wypetniania istotnych obowiqzzków matżeńskich. Przedstawieni przez powódke świadkowie wskazuja różne przyczyny niepowodzenia tego zwiqzku. W zwiazku z tym trudno powiedzieć, czy odgrywaly tutaj role jakieś trwate czynniki psychiczne, czy też ogól wydarzeń $i$ wzajemnych zachowań malzonkow poglębial rozklad zwiazku malżeńskiego".

5. Opinia bieglej jest klarowna i uzasadniona, materiał dowodowy rzeczywiście jest nader skąpy, glównie $z$ powodu odmowy pozwanego uczestniczenia w procesie. Brak informacji o cechach osobowościowych okazywanych przez strony w okresie przedślubnym, co w sprawach jak rozpatrywana ma duze znaczenie. Brak ten utrudnia rozpoznanie sprawy zwlaszcza, że obydwie strony funkcjonują zawodowo i cieszą się dobrą opinią środowiskową. Są jednak pewne fakty, na które nie sposób nie zwrócić uwagi.

Słusznie zwraca powódka w swym piśmie z 8.4.2002 uwagę na sprzeczność w stanowisku pozwanego zajętym 13.11.2000. Pisze bowiem, że „akceptuje unieważnienie związku malżeńskiego z p. J. D.”, ale nie zamierza ustosunkowywać się do zarzutów, co więcej grozi wystạpieniem do sądu powszechnego (nie dostrzegając rozdziału i niezależności jurysdykcji forum kościelnego i państwowego). Trudno przypuszczać, by pozwany nie orientowal się, że orzeczenie nieważności musi mieć podstawy. Skoro więc generalnie kwestionuje te podstawy, na czym opiera ,akceptację unieważnienia"? Wynikające stąd wątpliwości - także lącznie ze spostrzeżeniami wniesionymi przez świadków - nie wystarczają dla dokonania ustaleń odnośnie do zdolności pozwanego do funkcjonowania w malżeństwie, zwłaszcza, że na konflikty małżeńskie mogła wpływać odmienność koncepcji małżeństwa. Związanie się z hierarchiczną koncepcją małżeństwa, jaką wydaje się prezentować pozwany, nie czyni jeszcze niezdolnym do podjęcia obowiązków małżenskich. 
Wspomniane cechy pozwanego każą jednak Sądowi przypatrzeć się blizzej stanowi psychicznemu powódki w czasie zawierania małżeństwa (przy czym Sąd nie widzi powodów, by nie dać wiary jej zeznaniom w warstwie faktograficznej). Powódka mówi o kilkakrotnym zerwaniu znajomości przedślubnej, na co pozwany reagował zarzutem zmarnowania mu życia. Pozwany uderza w jej ,wrażliwe strony". Powódkę dręczą wyrzuty sumienia, rodzi się w niej konflikt, któremu nie potrafi sprostać - zasięga porad psychiatry i zażywa leki psychotropowe. Wedle zaświadczenia lekarskiego zaczęła zażywać te leki pól roku przed ślubem i przyjmowała je „stale” aż do końca roku. Decyzja powódki na zawarcie małżeństwa nie została podjęta dopiero po zażyciu środków psychotropowych, ale trwanie przy tej decyzji rodziło u powódki stany psychiczne wymagające zażywania silnych środków uspokajających. Nie chodzi o zażycie takich środków przed ceremonią ślubną, lecz o kilkakrotną konsultację psychiatryczną (,jak zobaczył, w jakim jestem zdanie” - zeznaje powódka). Nie był to stan mogący stanowić psychiczne podłoże woli małżeńskiej zdefiniowanej w kan. 1057. Wewnętrzne możliwości i wolność decyzji byly w poważnym stopniu ograniczone. Przeżywanie przez powódkę wytworzonej - zresztą przy jej początkowej akceptacji - sytuacji powodowało upośledzenie jej funkcji poznawczych i decyzyjnych w odniesieniu do małżeństwa. Zdaniem Sądu zachodził brak rozeznania, o którym w k. 1095 n. 2: powódka, osoba samodzielna i życiowo dojrzała, uwikłała się w konflikty wewnętrzne pozbawiające ją umiejętności rozważnego, krytycznego i autonomicznego spojrzenia na zawierane małżenstwo.

Przedmiotem sprawy nie jest jednak brak rozeznania, lecz niezdolność (w tym przypadku: powódki) do podjęcia istotnych obowiązków małżeńskich (k. 1095 n. 3). Są to dwa autonomiczne tytuly nieważności, aczkolwiek obydwa zakotwiczone w sferze psychicznej, nie zawsze dające się wyraźnie odgraniczyć, nieraz pozostające w konwergencji polegającej na tym, że defekt rozeznania może pociągnąć za sobą niezdolność do podjęcia istotnych obowiązków małżeńskich.

Nie ma powodów, by nie wierzyć powódce, gdy mówi, że starała się jak mogła, ,żeby wszystko było w porządku”, a zarazem, gdy twierdzi, że małżeństwo było dla niej ciężkim przeżyciem. Jeśli przyjąć, że - jak zeznaje ojciec powódki - pozwany powiedział jej matce (a także jeśli rzeczywiście tak sprawy postrzegał), iż nie wie, o co jej chodzi i dziwi się, że ona nie chce z nim żyć, to wniosek może być tylko jeden, ten 
mianowicie, że małżeństwo z pozwanym przerastało możliwości psychiczne powódki.

Biorąc powyższe pod uwagę Sąd stwierdza, że akta sprawy nie zawierają wystarczających dowodów na twierdzenie o niezdolności pozwanego do podjęcia istotnych obowiązków małżeńskich. Sąd osiągną1 natomiast moralną pewność, że powódka zawierając małżeństwo w stanie ograniczonego rozeznania nie była zdolna podjąć istotnych obowiązków małżeńskich. $Z$ tego więc tytułu Sąd uznaje nieważność małżeństwa za udowodnioną i niniejszym tę nieważność orzeka.

\section{La sentenza del Tribunale Metropolitano di Katowice (c. Sobański)}

del 13.10.1997 della incapacità (c. 1095, n. 3)

\section{Sommario}

Si presenta la sentenza (pro nullitale) del suddetto Tribunale emanata il 28 novembre 2002 . 